\title{
The Potential Role of Agro-Forestry in Honey Production-A Case Study of Federal College of Forestry, Oyo State, Nigeria
}

\section{${ }^{*}$ ADEKOLA, PJ; ${ }^{2}$ AYENI, OD; ${ }^{1}$ OLUWALANA, T; ${ }^{1}$ MAJEKODUNMI, OA; ${ }^{1}$ ADULOJU, AR; ${ }^{1}$ OKELEKE, SO}

\author{
${ }^{1}$ Federal College of Forestry Ibadan, Oyo State, Nigeria \\ ${ }^{2}$ Forestry Research Institute of Nigeria. Ibadan, Oyo State, Nigeria \\ *Corresponding Author Email: ayeniolatunji62@yahoo.com; adepop333@yahoo.co.uk; Tel: 08036673441,07081375931
}

\begin{abstract}
The major concern globally is the need to ensure health, economy, large food production, sustainable management of the environment and the renewable natural resources. Such concern has advance measure part of which generate up to date information necessary for long term exploitation of this resources. But this information itself requires planning as well as machinery for its management in Nigeria. However agro-apiculture/agro-forestry is still nonexistence. This is attributable partly to lack of understanding, information and awareness regarding agro-apiculture practice in forest plantation. And therefore, to create this awareness and draw of authority concerned-Governments, policy maker, town planning and municipal authority to the need for the incorporation of apiculture into agro-forestry for sustainable management. This fact therefore, justifies the growing interest in the apiculture with agro forestry. This paper focuses on the potential role of agro forestry in honey production in federal college of forestry since 1999 to 2016 and its associated environmental problems are highlighted while the potential of agro forestry in honey production are stressed.
\end{abstract}

DOI: https://dx.doi.org/10.4314/jasem.v24i11.6

Copyright: Copyright (C) 2020 Adekola et al. This is an open access article distributed under the Creative Commons Attribution License (CCL), which permits unrestricted use, distribution, and reproduction in any medium, provided the original work is properly cited.

Dates: Received: 20 September 2020; Revised: 29 October 2020; Accepted: 10 November 2020

Keywords: Honey production, Agro-forestry, Constraints and Endowment

Several pragmatic approaches to improve and alleviate problems as assumed a special climax in honey production among beekeepers especially in the third world. Honey and other hive products have been classified under non timber forest products which contribute immensely to GDP of many countries around the world. Since the early 1990's, the role of non-timber forest products [NTFPs] for sustainable forest management and poverty eradication has received increased attention (Adekola et al., 2002). NTFPs are fundamental for development and sustainable forest management and conservation strategies (Adekola et al., 2008). They play an important part in supporting household livelihoods and therefore can be used to raise the perceived value of forest resources. They act as incentives for more sustainable use of forest and woodland resources (Adekola, 2002). Honey production is the management of honey bees with a specific of producing honey and other bee product (Ayansola 2003). It is an ancient art that has been practice for several years in Africa, Europe, north and South America, Asia, and other parts of the world (Adekola, 2007). Honey is a sweet, thick and liquid substance compose mainly of simple sugar produced by honey bees from nectar of flowers which honey bees collect, transform and combine enzymatically with specific substance of their own, store and leave in honey comb to mature (Wilson, 2006). Production is a very lucrative and highly profitable venture. It is an enterprise that could rapidly generate commensurate with capital investment (Ayansola 2003). It could even be developed towards export oriented international market that can earn foreign exchange. Nutritionally, honey very rich in nutrients and it contains as many as 8 different substance which very important in human nutrition. Apart from proteins, carbohydrates, Organic acid, hormones, anti-microbial and anti-biotic element, honey contain very important minerals, trace elements as well as beta carotene salt (Adekola 2007). Agro-forestry contributes immensely to the production of honey through the pollination activities of bees. The apparent low rate of investment is partly due to dearth of information, incessant pest and diseases, indiscriminate bush burning, lack of interest of many policy makers etc. This paper therefore, elucidates the potential role of agro-forestry in honey production in Nigeria.

Agro-api-forestry development self-sufficiency means a national attempt at utilizing the country's domestic 
and honey bee products (such as, honey, wax, propolis, royal jelly, bee venoms, pollen and other food products). The main focus of self-reliant agroapiculture includes; (1) Reducing the importation of food and honey bee products for the supply of the required agro-api-forestry related goods and services (2) Improving reliance on domestic resources for the production and supplies of required agro-api-forestry goods and services. (3) Using an effective use of international trade policy controlling importation of goods and services and (4) An effective use of price control strategies for development of agro-api-forestry self-sufficiency for national development. Therefore, self-sufficiency in agro-api-forestry production is a relative term since it can produce everything that it needs on its own. Hence, for the present need, Nigeria sufficiency in agro-api-forestry means the ability and capability to produce enough of the major stable foods, trees and honey bee products necessary for the survival of the people and constant supply of raw materials for industries. This also includes capacity to maintain peace and order in the country. And, the storage, preservation and distribution of different types of food item from one place to another and at a time needed. Moreover, in the case of deforestation situation or natural disaster such as unfavourable climatic and socio-economic condition and so on. There must be a policy and energizing research activities to identify, prevent and stabilized those factors which could promote a country's selfsufficiency capabilities at any time of needs.

\begin{tabular}{|c|c|c|c|c|c|c|}
\hline Years & $\begin{array}{l}\text { No of } \\
\text { hives }\end{array}$ & $\begin{array}{l}\text { No of } \\
\text { colonized } \\
\text { hives }\end{array}$ & $\begin{array}{l}\text { No of } \\
\text { bee } \\
\text { products }\end{array}$ & $\begin{array}{l}\text { Quantity } \\
\text { produced(L) }\end{array}$ & $\begin{array}{l}\text { price/ } \\
\text { bottle }) \\
\left(=\mathrm{N}^{=}\right)\end{array}$ & $\begin{array}{l}\text { Total } \\
\text { yield }) \\
\left(=\mathrm{N}^{=}\right)\end{array}$ \\
\hline 1999 & 1 & 0 & 0 & 0 & 0 & 0 \\
\hline 2000 & 1 & 0 & 1 & 12 & 250 & 4,258 \\
\hline 2001 & 1 & 0 & 0 & 0 & 0 & 0 \\
\hline 2002 & 1 & 1 & 2 & 14 & 250 & 3,300 \\
\hline 2003 & 4 & 3 & 2 & 10 & 300 & 3.400 \\
\hline 2004 & 6 & 5 & 2 & 13 & 300 & 9,600 \\
\hline 2005 & 6 & 5 & 0 & 0 & 0 & 0 \\
\hline 2006 & 6 & 0 & 0 & 0 & 0 & 0 \\
\hline 2007 & 6 & 5 & 2 & 0 & 0 & 0 \\
\hline 2008 & 6 & 5 & 0 & 0 & 0 & 0 \\
\hline 2009 & 10 & 5 & 2 & 40 & 530 & 22,400 \\
\hline 2010 & 10 & 5 & 2 & 25 & 500 & 25,000 \\
\hline 2011 & 10 & 5 & 2 & 23.5 & 500 & 23000 \\
\hline 2012 & 10 & 5 & 2 & 12 & 500 & 12,000 \\
\hline 2013 & 10 & 5 & 2 & 18 & 1,500 & 18,000 \\
\hline 2014 & 14 & 5 & 2 & 10 & 1,500 & 15,000 \\
\hline 2015 & 14 & 5 & 2 & 21 & 1,500 & 21,000 \\
\hline 2016 & 14 & 6 & 2 & 27 & 1800 & 48,600 \\
\hline
\end{tabular}

To improve agro-forestry in apiculture for selfsufficiency, the spirit behind it must be highly recognized and standardized. Therefore, to achieve self-sufficiency in agro-api-forestry the following arguments are included: (1) Agro-api-forestry goods serve as a weapon for defensive and offensive purpose. Self-feeding capacities are a natural development of a country. (2) There must be reduction in money spent on procuring of local food, tree crops and such funds should be used for saving our investment which will enhance the living standard of people in the country. (3) This is the time for Nigerian to wake up to provide enough food needed for the people to survive. The reasons for this is that Nigerian is bless with both potential human and natural resources to revive agroapicultural productivities for both local and export uses. (4) Agro-apicultural self-sufficiency serves as bedrock for revitalizing industrial development. Thus, improving the living condition of people in Nigeria. (5) A self-relent agro-apicultural sector is a huge employer of labour and can accelerate and stabilized the industrial development of a country. (6) To improve the health standard in a country like Nigeria by producing a higher proportion of vitamins, proteins and mineral through agro-apicultural productivity development. (7) A wide variety of products such as food, crops, fodder, honey and other bee products are sustainable harvested from one land unit. (8) Agroapi-forestry gives farmer opportunities to diversify production, by growing many agricultural crops and honey bee products within the same area at the same time. Thus, they minimize the risk of having a reduced income should one of their crops fail or the market price drops. According to Sanwo and Adedoyin (2006). Many experiments have shown that the aggregate yield of diversified production exceeds the yield of a single crop. (9) Domestication of honey bee with agro-forestry crops ameliorates microclimate and thus increase crops production. Since land contribute a vital role in production, the land use act of 1979 should be reviewed and it is paramount that land ownership defined a web of right and obligation so as 
to maintain agro-api-forestry for self-sufficiency in Nigeria. Also, effort should be made towards rural development programmed to facilitate egalitarian agro-api-forestry for self-sufficiency access to land. Thus, improve and raise awareness in agro-forestry for honey production and train farmers and students on importance of agro-forestry in honey production with enhance skills in production of agro-forestry in honey production and then improve human well-being and enhance livelihood

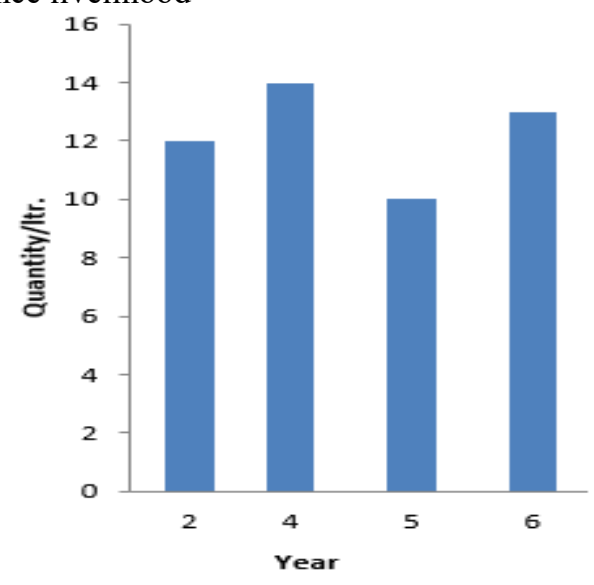

Fig 1. Quantity of Honey produced from 1999 - 2008

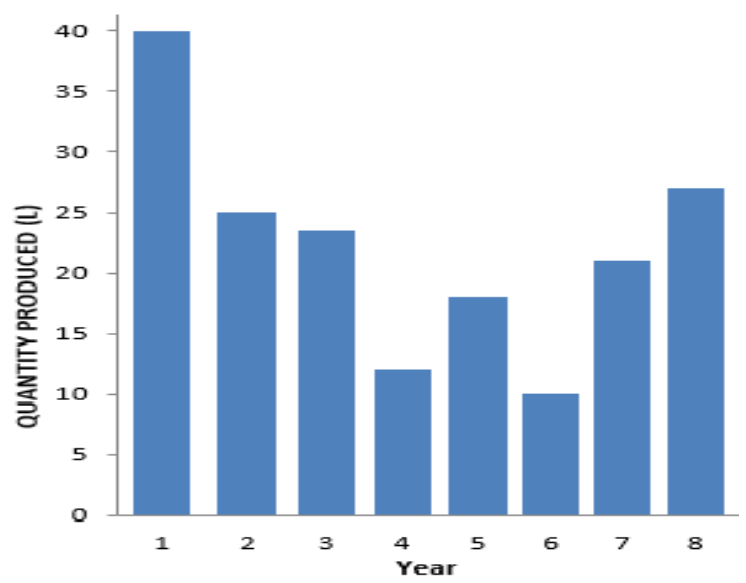

Fig 2. Honey produced on Agroforestry plantation from 2009 2016

\section{RESULT AND DISCUSSION}

The table above shows the effect of agro- apiculture on honey production between 1999 -2016. From the table it was observed that there was a significant increase in honey production when arable crops were integrated within the apiary thereby forming an agro forestry system. Previously, apiculture was carried out in a secluded area without the inclusion of arable cropping within the periods of 1999-2008 and this had yielded a range of liters of honey produced which fluctuated over this period from 10 to 14liters, although it was observed that certain factors played a major role in the fluctuations of honey produced such as pests and diseases, lack of adequate equipment, disturbance of the hives due to constant relocation, honey bee absconding and fire invasion. Moreover in the year 2009, when the hives were integrated with arable crops (agro-forestry), it was observed that that there was a significant increase in honey production, with a yield of 14 liters in 2008 to 40 liters in 2009 with the same number of hives, this is simply due to the incorporation of arable crops with apiculture (agro forestry). This system offers an environment of low disturbances and multi floral components which offered a greater variety and quantity of pollen for foraging by the bees. This revealed the rates of honey production from 1999-2002 with only one hives, the highest production was 14liters, from 2004-2008 with 6 hives the highest production was 13 liters, between 2009-2013 with 10 hives the highest production was 40liters and between 2014-2016 with 14hives the highest production is 27 liters. The low production rate is due to pest and diseases attacks, indiscriminate busy burning, lack of permanent land, inadequate facilities etc. In conclusion, it is suggested that agro-forestry has immense benefits for all sectors of apiculture as it offers a more natural and organic environment for apiary sitting.

Conclusion: From the foregoing, the writers in this paper attempt to examine the various possibilities and options that may be adopted to make Nigeria a selfsufficient Agro-api-forestry nation. In order to alleviate food, trees and honey bee production crises, there is need to introduce new policy that will promote agro-api-forestry in Nigeria. There should be focus on programmes that are mostly concern about our environment and daily activities. The emphasis should be laid on adequate allocation of resources for a genuine agro-apic-forestry development. There must be effective motivation techniques for producers and coordination mechanisms that promote agro-apicforestry self-sufficiency for national development. In conclusion, it is high time for Nigeria to wake up to set out a pragmatic programme that will promote food, planting of trees and honey bee production, thus, improve human and natural resources as to provide better standard of living for the people in the country.

\section{REFERENCES}

Adekola, PJ; Ogundele, OJK; Babatunde, TO; Ayoola, OA. (2005). Pre-requisite for the development of sustainable Agro-apiculture in Nigeria. Multidip. J. Res. Develop. 7. 4-8

Adekola, JP; Ojo, MO; Samuel, AA; Aderounmu, AF (2006): Apiculture in Nigeria: A viable source of livelihood. J. For. Res. Manage. 3:59-69. 
Adckola, J.P., Omoyajowo, A.O., Ojo, M.O., Fagbenro, J.A. (2007): Wealth and Health Generation through Honey Production for Sustainable Development in Nigeria Proceeding of the 5th International Conference of the Nigeria Society for Experimental Biology (NISEB), Kogi State University, Anyigba, Kogi State 28th -3rd March 2007.

Ayansola, B. (2003); Honey bee; Bioecology, Honey Poduction and Utilization. Trankhei and Co. (Publishers) Ibadan, Nigeria. p.66

Bobadoye, BO; Adekola, PJ; Adris, M; Oyenue, EB (2012): Improving rural community lively hood of women using beekeeping. A paper presented at international conference of Women in Agriculture, Indian, March, 2012.
National population commission (NPC): (2001) Federal Republic of Nigeria Development Cooperation 1998/1999 Nation planning commission.

Ogah, C.A., and North, I.N., (2009): Agriculture Development policy issues for self-sufficiency misusage against food crisis in Nigeria. Pp 7-10

Sanwo, SK; Adedoyin, SF (2006) promoting Agroforestry among rural farmers in Nigeria. Paper presented for Development of Renewable Resources Onabajo University, Yewa campus Ogun State. Pp. 4

Wilson, RT (2006) Current Status and Possibilities for Improvement of Apiculture in Sub-Saharan African. Livestock Res. for Rural Develop. 18 (8) $1-11$. 